\title{
Educating the Future with Disruptive e-Learning Solutions
}

\author{
Merija Jirgensons \\ Distance Education Study Centre (DESC), Riga Technical University, Riga, Latvia
}

Keywords: Disruptive Innovation, Disruptive e-Learning, Discovery Driven Planning, MOOCs.

\begin{abstract}
Learning is having a strong impact on Higher Education. It is reinventing approaches to education and is causing sharp debates among its practitioners about the future direction of learning. Advocates argue that elearning is a viable option to combat the high cost of higher education; that it extends educational opportunities to a greater number of students; that it trains students for the emerging Knowledge Economy. In fact, the e-learning education market has seen a continuous influx of new players; not only are traditional universities going online, but for-profit universities are emerging, some having a global reach, and most recently MOOCs (massive online open courses) that are offered as online education for free-many from elite universities that were the last to go online. These developments have created debates over assessment and accreditation. Educator Clayton Christensen calls e-learning "the great disrupted" that is transforming the higher education landscape. Yet even with the steady increase of e-learning options, e-learning is still regarded as inferior to traditional forms of learning. Critics regard is as too business and vocationally orientated, unmindful of questions of quality. This paper looks at some of the issues surrounding the controversy of e-learning options and makes some recommendations as to its improvement.
\end{abstract}

\section{INTRODUCTION}

e-Learning has challenged fundamental assumptions about how we learn and what we learn; how learning is to be delivered and how accessed. It has even opened up a sharp debate about the purpose of education; the values for which it stands and the competencies that it aims to teach. To quote Harvard Business School Professor Clayton Christensen, e-learning is proving to be the great disrupter of traditional education reinventing approaches to learning (Christensen and Eyring, 2011; Christensen, Horn, and Johnson, 2011). The process is already underway and appears to be accelerating. The reasons are not difficult to find. Caught between the pressures of rising higher education costs, the need for high level skills for the emerging knowledge economy, and rapid technological advances, new learning approaches are being invented that seek to take advantage of technological innovations and shape them into credible learning tools. E-learning has benefitted from this trend and has sought to present options that are viable and offer innovative solutions at lower cost and engaging forms of delivery. Increasingly new methods and approaches are being explored by this media: hybrid learning, virtual learning, mobile learning, and most recently MOOCs. At Riga Technical University in Latvia, the eBig3 project combined the communication technologies of computer, mobile, and TV to gain broad public interest. Most recently the project also offered MOOCs (ERDF, eBig3). But education via technology has incited much controversy as well as debates over the direction of education in general. Provoking such fundamental questions as: is technology learning too business orientated? What about humanistic values? What about quality? Is traditional education too elitist? Should education be more vocationally orientated? Or can we somehow combine some of these values or even should we? Its advocates claim that technology promises a fantastic future for educational engagement. Technology based learning, however, is too new for longitudinal studies; at this point, positive studies seem to generate critical studies and vice-versa. Yet the technology will not go away; it continues to spew out innovations apace. Therefore it is worthwhile to look at Clayton Christensen's--one of the most respected e-learning advocates--arguments supporting e-solutions. He claims that prevailing trends signal that online options are the inevitable 
future of higher education (Christensen and Eyring, 2011: 328). Christensen has outlined his ideas in considerable detail. These recommendations are worth looking at although by no means do they settle the controversy.

\section{CHRISTENSEN'S DISRUPTIVE E-LEARNING}

Clayton Christensen is the author of "Disruptive Innovation", a theory that he first outlined in the Innovator's Dilemma (1997). He had originally meant it to apply to business (he holds a joint appointment at Harvard in technology and management). The idea had come out of his dissertation, and he had meant it to apply to the disk drive industry. But the idea was quickly co-opted; many managers believed the process described their own experience. Christensen came to realize that "Disruptive Innovation" described a general business model. And because he was engaged with computer technology, he recognized that the model also applied to e-learning. The way disruptive innovation works, is that it is applied in areas where there is no competition. Slowly, and out of sight the company / organization improves its product. Soon there is an alternative product on the market that is cheaper and of better quality than the dominant one; and if the alternative product is more attractive to consumers, the dominant product can be toppled. This is what happened to Kodak with digital films, or how Cannon managed to trump Xerox or Sony with its transistors clobbered RCA's vacuum tubes. Christensen cautions against taking major competitors head-on--a good way for a company to get bloodied. Instead, he claims, disruptive innovation works against non-consumption-it stakes out a new territory-and improves its product step-by-step. When by its success a product or an approach is shown to work, it becomes a fait accompli and may even come to dominate the market (Christensen, Horn, and Johnson, 2011: 141) As applied to e-learning, Christensen refers to it as “disruptive e-learning.” It is the crux of his strategy for effective education that is democratizing and can reach almost anyone. He believes that disruptive elearning can bring about student centered learning that he argues is the focus of quality teaching. He is opposed to traditional learning because he regards it as a monolithic, top-down approach or teachercentered and refers to it as batch learning (Christensen, Horn, and Johnson, 2011:175).
Christen argues for a modular course design where the parts are interchangeable. He also calls for modified "majors" where students may become experts in several areas instead of concentrating on one and where independently designed course "modules" allow them to move easily between different subjects. Microsoft is an example of the "batch system", the programs are interdependent; they are part of a system. If you use one, you must use the entire system. Moreover, they are expensive to build. Simplify - argues Christensen - the byword that informs his disruption strategy. He claims that a simplified modular architecture such as offered by Linux allows for the building of separate modules. It is cheaper and more flexible and the heart of disruptive design. Its simplicity and low price allow it to be customized by users. A modular approach also gives students the flexibility to move on to the next module without wasting time on concepts and materials they already understand. It is an important option for bringing about student centered online learning. The next step in this strategy is to make use of popular apps and user generated content. Among these are those generally well known to the public such as eBay, YouTube, Pixar for digital animations, and Second Life for 3D applications. He recommends technology platforms that are suitable even for nonprofessionals such as QuickBase for designing user generated content. Parents and teachers can develop programs that will help their children learn. This mixture of disparate content, he argues, can have wider application because it can become the basis for shaping successful e-courses. Central to this thinking are teacher and student networks such as teacher online sites to exchange information and lesson plans and student self-help and tutoring sites, such as Megastudy in South Korea (Christensen, Horn, and Johnson, 2011: 134145). Mentoring, but especially peer mentoring, is central to Christensen's concept of student centered learning. Christensen, like many teachers, feels that students have difficulty in grasping the relationship between theory and practice; that they memorize a theory but have difficulty understanding how it may be applied to real life solutions. Peer mentoring, he feels, can help students break down complex ideas and show how they work in various real-life contexts. Peer support is especially important for atrisk students who may feel stressed by academic materials. A number of the peer support sites are available online, and Christensen feels they should be included in an e-course design. Christensen admits that this disparate, user-generated content looks more like tutorial tools rather than courseware, 
but over time, he claims, these modules can be configured into complete courses. Disruptive innovation starts small and gradually builds up as the demand increases. It is a grassroots approach to e-learning that expresses an intriguing departure to standard academic learning.

Since disruptive innovation never applies the head-on attack, Christian recommends that this usergenerated learning should take effect on the fringes. $\mathrm{He}$ points out that innovations when officially presented are often co-opted by organizations and rendered innocuous by official policy or pulled apart in turf fights. Instead, he suggests, disruptive elearning should take root in places where there is a "consumption gap." Students re-taking courses to fill a "credit-gap," home bound schooling, assisting atrisk students, tutoring and enrichment programs, or making available courses that cannot be added to the curriculum because of budgetary constraints. Rural, small schools, urban low-income schools, could benefit from such an approach. This e-solution is an alternative when there is nothing at all and is a case in point how disruptive innovation, or in this case disruptive e-learning, is embedded into a system and can provide an alternative, a richer education experience than the one that existed before. The learning of the future, Christensen predicts will be driven by student-centered technology innovations (Christensen, Horn, and Johnson, 2011: 99).

\section{HELPING AT RISK SUDENTS WITH DISTRUPTIVE E-LEARNING}

Christensen is a dedicated social crusader. His Innosight Institute is committed to applying the transformative power of disruptive innovation to the social problems of the day. Educational reform at all levels he regards as crucial. He details the Pathway program at Brigham Young University at Idaho (Christensen is an alumnus of Bingham Young University, Utah and remains closely associated with the university's activities) as a model for upward mobility for the academically challenged and at-risk student group. It is an online program that requires weekly face to face meetings and encourages peer interactions. It reflects the indirect, non-aggressive approach of disruptive elearning that is the cornerstone of Christensen's thinking. The Pathway program seems a sensible step by step plan for the inclusion of the academically challenged and socially and economically disadvantaged. Pathway runs parallel to the regular university curriculum. The standards of admission are low. It is intended for older, at risk students who need to support themselves and a family. The program designers understand that the primary concern of these individuals is the need to earn a living. The first part of the program offers technical competence courses in basic accounting, web media design, basic legal and library research, skills that are immediately marketable. Upon the successful completion of the program, students receive a certificate. They may then go on the next level that is an Associate Degree, and, if that is successfully completed, a Bachelor's (Christensen and Eyring, 2011: 315). It is a Matryoshka doll structure where each significant academic achievement is nested within the next. It gives students the option at the end of each learning level to finish or to continue to a more advanced degree while at the same time being able to provide for themselves and their families. The cost of a Bachelor's degree is about $\$ 8,000$, a fraction of the cost what it would cost at a medium level, accredited university (What is Pathway).

\section{THE WIDER IMPLICATIONS OF DISRUPTIVE INNOVATION}

How relevant are Christensen's ideas today in the field of technological innovation? Jena McGregor claims very. In her interview with Christensen for Bloomberg Businessweek she describes him as is a giant in the field of innovation thinkers (McGregor, 2007). What has changed since 1997 when the Innovator's Dilemma was first published is that the landscape has gone global. It is in flux and the behavior of the players is unpredictable. Yet the notion of disruptive innovation still resonates although the model is felt to be too simple to explain this complex scenario. Moreover, Christensen did not originally provide a solution for his model; he only described phenomena that he had observed and that is now being played-out on a global scale. The Rita McGrath and Ian MacMillan model (McGrath and MacMillan, 1995) presents a method to structure phenomena when outcomes are uncertain and could be used to structure disruptive innovation. Traditional planning projected outcomes for projects; if the outcomes matched the projections, it was considered valid; if not, it was regarded as deficient. But Discovery Driven Planning seeks to 
promote innovation. It turns conventional thinking on its head. It encourages the new in a controlled way. Results are tested at benchmarks, assumptions are questions and articulated and then the next steps are planned from the results (McGrath and MacMillan, 1995). It means a commitment to continuous learning on the part of project managers. Moreover, just because an innovation is in place does not mean it will maintain itself in the future; instead it must be reassessed on an ongoing basis. Christensen feels when his ideas are combined with those of Discovery Driven Planning a sounder assessment of an innovation is arrived at as well as its potential for success (McGregor, 2007). These ideas could be applied to disruptive e-learning to give it a more structured development that at present seems erratic. is endorsed by pragmatists such as Christensen but decried by the quality advocates. Yet there are issues that reformers of all shades of opinion agree: (1) that higher education costs are too high; (2) that there is a proliferation of majors that are proving costly and often force students to postpone graduation to meet requirements; (3) that students are not prepared to deal with the requirements of university courses and need structured support embedded in the program (What is Pathway; Christensen and Eyring, 2011). These three points are the main challenges that must be met to achieve realistic educational reform. Technology must be a major driver, not only because it helps to reduce costs, but even more so because it gives students access to the emerging Knowledge Economy and its potential for innovation.

\section{COUNTERING THE COST OF HIGHER EDUCTION WITH SUNDRY E-LEARNING SOLUTIONS}

Currently, there are many emerging models for higher education. Most of these are online. Besides online courses offered by traditional universities, there are the for-profit universities mostly with online options, some of which have become global giants such as Laureate whose honorary chancellor is Bill Clinton (Redden and Fain, 2013). This development has also set up a credentials debate and proposals for alternative credit assessment. Even President Obama has entered the fray and made recommendations to combat rising college costs that include competency credit and MOOCs (Obama, 2013; Levin, 2013). Richard Vedder, author of Going Broke by Degree: Why College Costs So Much (2005), argues for a pro-business, no frills program that makes use of lower priced online options such as the new entrants MOOCs, a three year Bachelor's program as in Europe, and most controversial of all, a National College Equivalence Test similar to GED for the High School Equivalence test (Vedder, 2013). Needless to say, such a reductionist program has elicited howls of protest from educational purists who claim that these HiTech reformers leave out questions of quality and the importance of education as an intrinsic value leaving only a thin vocational, pro-business veneer (Walters, 2013). Moreover, they point out that the proposed system of online reform would increase student / teacher ratio 50:1; a dramatic increase that

\section{AND THE DEBATE GOES ON}

In the mist of so much controversy the signals about the future of e-learning are mixed, although generally favorable for long-range growth. As many as $69.1 \%$ higher education institutions in the United States report that online learning is critical to their long term strategy (Allen and Seaman, 2013). In the United States where technological solutions to learning are most actively embraced, online learning has steadily increased over the past ten years, so that currently thirty-two percent of the students are taking a least one e-learning course. Yet last year there was a perceptible leveling off of enrollments, increases dropping from an $11.2 \%$ to $9.3 \%$ although university officials agree that online learning is critical to their long- term strategy (Allen and Seaman, 2013). Europe has been more conservative in adopting e-learning; in 2011 (published in 2013) for the EU-27, 11\% of their populations (ages 16 to 74) were engaged in online learning. In the same time period, Latvia was one of the more active with $16 \%$ of its population (ages16 to 74 ) were engaged in online learning, exceeded only by its Nordic neighbors (European Commission, 2013). The most recent entrants to the technology learning market are MOOCs (Massive Online Open Courses). They have been touted as the next educational paradigm; yet currently there is a great debate if they are sustainable (Allen and Seaman, 2013). These are open access courses that cut across a wide range of disciplines including technology, philosophy and even music. Besides course materials that include various media formats, MOOCs seek to establish online forums and learning communities similar to 
what traditional e-learning courses already offer. An interesting development in this regard is that the elite universities that were slow to adopt online learning, were first to jump on the MOOCs bandwagon. Harvard as recently as 2013 and is currently engaged in developing its first regular online courses for the Business School—"we are being disrupted online,” HBS claims (Nissen, 2013). There are online listings of elite USA universities that start with Harvard and MIT and include Apple's list that is a comprehensive MOOCs listing (MOOCs). Most of these use Coursera or Udacity or another popular platform. Currently there is much debate if MOOCs are sustainable. Academics generally think that MOOCs will cause much confusion about university degrees and credentials (Allen and Seaman, 2013). The shrillness of this debate indicates that there is indeed a transformation taking place and that the stakeholders have not settled on the terms of the outcome.

In spite of resistance and challenges, the statistics show a steady increase of e-learning for the future. Christiansen no doubt is right that it will lead to a disruption of traditional forms of learning as it already seems to be doing. Transformations are taking place that are affecting even the most highly respected Higher Education Institutions. Yet barriers and prejudices remain. Many people, including academics, resist accepting e-earning as the equal to face-to-face learning. Employers often regard it as inferior. Moreover, the record of the retention rate of on-line students has been poor. Many drop out before finishing the course (Allen and Seaman, 2013). It is possible that these students are academically poorly prepared and lack selfdiscipline although other studies have shown that the technology does not usually pose a barrier to the current generation of students, but rather they may lack motivation, study skills and have family responsibilities (Concannon, Flynn, Campbell, 2005). The immediate issues that need to be addressed in Higher Education reform is controlling the costs and making education more affordable - an issue that can effectively be addressed by e-learning. The second issue is about the proliferation of course for majors that often hold up graduation. Christensen's modular approach that is spread out over several disciplines seems far more sensible to replace the traditional major and gives students more options in planning careers. And finally, users who are at risk need help and support, including financial support; they need a gradual, clearly benchmarked program such as Pathway or another structured approach to be able to succeed in a e-learning environment.

\section{ACKNOWLEDGEMENTS}

This paper was partially funded by the European Regional Development Fund (ERFF), Project Jauzi (Eng. Trans.: New User behavioural interpretation algorithms to facilitate an efficient transfer of knowledge within an e-ecosystem) Nr. 2013/0071/2DP/2.1.1.1.0/13/APIA/VIAA/023.

\section{REFERENCES}

Allen, I. Elaine and Seaman, Jeff (2013) Changing Course: Ten Years of Tracking Online Education in the United States, Babson Park, MA: Babson Survey Research Group and Quahog Research Group. http://www.onlinelearningsurvey.com/reports/changin gcourse.pdf (accessed 10/09/2013)

Auguste, Byron G., Cota, Adam, Jayaram, Kartik, Laboissière, Martha C.A. (November 2013) Winning by degrees: the strategies of highly productive highereducation institutions, McKinsey http:// mckinseyonsociety.com/winning-by-degrees/ (accessed 11-2-2013)

Christensen, Clayton M. and Eyring, Henry (2011) the Innovative University, San Francisco, CA: JosseyBass.

Christensen, Clayton M, Horn, Michael B, and Johnson, Curtis B. (2011) Disrupting Class, New York: McGraw Hill.

Concannon, Fiona, Flynn, Antoinette and Campbell, Mark (2005) "What campus-based students think about the quality and benefits of e-learning," British Journal of Educational Technology 36(no. 3), 501-512

European Commission, EuroStat, Glossary: E-learning, Information society statistics, http://epp.eurostat. ec.europa.eu/statistics_explained/index.php/Informatio n_society_statistics (accessed 28-12-2013).

European Regional Development Fund (ERDF), eBig3, synergetic approach with eLearning, TV and mobile technologies to promote new business developments, Project No. LV-LT/1.1./ LLIII-183/2011/26

Levin, Tamar (August 22, 2013) Obama's Plan to Lower College Costs, New York Times

McGrath, Rita Gunther and MacMillan, Ian C. (JulyAugust, 1995) “Discovery-Driven Planning,” Harvard Business Review, Reprint 95406

McGregor, Jena, "Clayton Christensen's Innovation Brain”, Bloomberg Businessweek, June 15, 2007 http://www.businessweek.com/stories/2007-0615/clayton-christensens-innovationbrainbusinessweek-business-news-stock-market-andfinancial-advice (accessed 10-10-2013) 
MOOCS: Top 10 Sites for Free Education with Elite Universities http://www.bdpa-detroit.org/portal/index. php? Itemid=20\&catid=29:education\&id=57:moocstop-10-sites-for-free-education-with-elite-universities \&option=com_content\& view=article (accessed 1210-2013).

Nissen, Max, "Now Even Harvard Business School is Working On Online Courses," Business Insider, Oct 10, 2013. http://www.businessinsider.com/harvardbusiness-school-online-courses-2013-10 (accessed 12-10-2013)

Obama, Barak President (August 22, 2013) President Obama Explains his Options to Combat Rising College Costs, The White House Blog, http://www.whitehouse.gov/blog/2013/08/22/president -obama-explains-his-plan-combat-rising-college-costs (accessed 13-09-2013).

Redden, Elizabeth and Fain, Paul (Oct 11, 2013) "Going Global," Inside Higher Ed.

Vedder, Richard, "How to Slash College Costs," CNN Edition: International, Aug 23, 2013 http://edition.cnn.com/2013/08/23/opinion/veddercollege-costs/index.html?iid=article_sidebar (accessed 12-10-13)

Walters, Garrison, (April 11, 2011) "More Degrees Dollars-Damn the Quality"? Inside Higher Ed

What is Pathway? Brigham Young University /Idaho, http://www.byui.edu/online/pathway/what-is- pathway (access 12-10-13) 